\title{
PENGARUH PENGGUNAAN MEDIAL ARC SUPPORT TERHADAP TINGKAT KELELAHAN DAN STRESS PADA PENDERITA FASCITIS PLANTARIS
}

\author{
Yopi Harwinanda Ardesa, Cica Tri Mandasari Ningsih, Muhammad Syaifuddin \\ Kementerian Kesehatan Politeknik Kesehatan Surakarta Jurusan Ortotik Prostetik
}

\begin{abstract}
Plantaris Fascitis, Medial Arc Support, Fatigue, Stress. This research purpose to know the effect of Medial Arc Support in patients with plantar fascitis against fatigue and stress on employees packing PT TPS Food TBK. Experimental studies using quantitative methods to approach one group pretest-posttest design. The study population was all employees at PT TPS Food packing TBK suffering from plantar fascitis. To measure the reduction of pain in the plantar fasciitis with measuring tools such as Visual Analoc Scale by taking data on the day before treatment done and a day after the last treatment carried out (4 weeks). Examination carried out under pain painful motion, silent pain, and tenderness. Examination of pain before and after treatment. The results showed the average pretest fatigue patients with plantar fasciitis (24.60) while the average post-test (20.20). Wilcoxon test results showed statistical p value 0,000<0,05 so that there is influence of Medial Arch Support to decrease fatigue in patients with plantar fasciitis. With the conclusion of the conclusions There is the influence of Medial Arch Support to decrease stress levels in patients with plantar fasciitis with $p$ value 0,000 <0,05. There is the influence of Medial Arch Support to decrease fatigue in patients with plantar fasciitis with $p$ value 0,000<0,05.
\end{abstract}

Keywords: Plantaris Fascitis, Medial Arc Support, Fatigue, Stress

Abstrak: Fascitis Plantaris, Medial Arc Support, Kelelahan, Stress. Tujuan Penelitian Mengetahui pengaruh Medial Arc Support pada penderita Fascitis Plantaris terhadap kelelahan dan stress pada karyawan packing di PT TPS Food TBK. Dengan Metode Penelitian eksperimental kuantitatif menggunakan pendekatan rancangan one group pretest posttest. Populasi penelitian adalah semua karyawan packing di PT TPS Food TBK yang menderita fascitis plantaris. Untuk mengukur penurunan nyeri pada fasciitis plantaris dengan alat ukur berupa Visual Analoc Scale dengan mengambil datanya pada sehari sebelum terapi dilakukan dan sehari setelah terapi terakhir dilakukan (4 minggu). Pemeriksaan nyeri dilakukan pada kondisi nyeri gerak, nyeri diam, dan nyeri tekan. Pemeriksaan nyeri dilakukan sebelum dan sesudah perlakuan. Hasil penelitian menunjukkan rata-rata pretest kelelahan penderita plantar fascitis $(24,60)$ sedangkan rata-rata postest $(20,20)$. Hasil uji statistik dengan wilcoxon menunjukkan $p$ value 0,000 < 0,05 sehingga terdapat pengaruh Medial Arch Support terhadap penurunan kelelahan pada penderita plantar fasciitis. Dengan kesimpulan kesimpulan Ada pengaruh Medial Arch Support terhadap penurunan tingkat stress pada penderita plantar fasciitis dengan $p$ value $0,000<0,05$. Ada pengaruh Medial Arch Support terhadap penurunan kelelahan pada penderita plantar fasciitis dengan $p$ value $0,000<0,05$. 
Kata Kunci : Fascitis Plantaris, Medial Arc Support, Kelelahan, Stress

\section{PENDAHULUAN}

Perkembangan di sektor industri menuntut dukungan penggunaan teknologi maju dan peralatan modern, namun demikian kebutuhan tenaga kerja di bidang industri masih sangat tinggi. Hal tersebut disatu pihak dapat memberikan kemudahan dalam proses produksi dan meningkatkan produktivitas serta dampak positif terhadap kesehatan, seperti meningkatnya penghasilan pekerja, kondisi tempat tinggal yang lebih baik dan peningkatan pelayanan.

Namun di lain pihak penggunaan teknologi maju cenderung untuk menimbulkan risiko bahaya kecelakaan dan penyakit akibat kerja yang lebih besar, baik di tempat kerja maupun di masyarakat pada umumnya. Dengan kata lain, adanya perubahan kearah industrialisasi tersebut dapat menyebabkan perubahan pola penyakit yang berhubungan dengan pekerjaan. Salah satu penyebab pola penyakit yang berhubungan dengan pekerjaan adalah masih banyaknya tenaga kerja yang mendapatkan pekerjaan dengan posisi berdiri.

Bekerja dalam posisi berdiri untuk jangka waktu panjang secara teratur bisa menyebabkan kaki sakit, pembengkakan kaki, varises, kelelahan otot umum, nyeri pinggang serta kekakuan pada leher dan bahu, seperti dikutip dari Canadian Center of Occupational Health and Safety, Sabtu (23/42011). Hal ini karena tubuh dipengaruhi oleh pengaturan daerah kerja sehingga membatasi posisi-posisi tubuh pekerja dalam beraktivitas. Akibatnya tubuh pekerja hanya memiliki sedikit kebebasan bergerak dan menjadi lebih kaku. Kurangnya fleksibilitas tubuh akan menyebabkan masalah kesehatan. Bekerja dalam posisi berdiri pada jangka pendek akan menimbulkan ketidaknyamanan dan akhirnya jika berlangsung terus menerus bisa mengakibakan masalah kesehatan yang parah dan kronis.

Posisi berdiri secara biomekanis pergelangan kaki merupakan bagian tubuh yang menerima beban dari seluruh tubuh baik pada saat berdiri maupun berjalan. Pada saat berjalan atau berlari maka beban tubuh diterima oleh kaki atau pergelangan kaki pada kedua sisi secara bergantian. Oleh kerena kaki dan pergelangan kaki menjadi pusat tumpuan badan pada saat berdiri, berjalan dan berlari, maka bagian tubuh tersebut cenderung mengalami gangguan akibat trauma mekanik yang terjadi terus-menerus yang menyebabkan nyeri pada pembebanan yang berlebihan salah satunya adalah plantar fasciitis.

Nyeri terjadi pada awal gerakan baik saat berdiri maupun berjalan. Nyeri terasa tertusuk-tusuk pada daerah tumit bawah yang merupakan suatu masalah yang paling sering dijumpai, nyeri pada tumit ini bisa disebabkan karena beban yang berlebihan pada telapak kaki yang mulai atau telah degeneratif, biasanya dialami oleh orang dengan berat badan yang besar atau obesitas serta kebiasaan menggunakan alas kaki yang permukaannya keras dan tipis, dan juga pada seorang yang mempunyai arcus yang tinggi dan flat foot. Pada beberapa kasus, nyeri muncul ketika mengangkat beban berat karena adanya penekanan pada fascia plantaris. Nyeri dapat menyebar sampai ke dasar kaki bahkan sampai ke ujung kaki. kesakitan yang amat sangat ketika otot harus melakukan beban dapat mengakibatkan kelelahan otot. 
Karena adanya nyeri tersebut maka terjadi immobilisasi yang efeknya akan memunculkan masalah baru salah satunya adalah terjadinya disuse atrophy dan akibat selanjutnya akan mengganggu produktifitas yang pada akhirnya berdampak pada penurunan kualitas hidup, baik fisik maupun mental. Kelelahan secara umum merupakan suatu perasaan yang menyebar yang disertai dengan adanya penurunan kesiagaan dan kelambatan pada setiap aktivitas dan dapat menjadi gejala penyakit yang berhubungan dengan faktor psikologis (motivasi menurun, kurang tertarik) yang mengakibatkan menurunnya kapasitas kerja.

Timbulnya rasa lelah dalam diri manusia merupakan proses yang terakumulasi dari berbagai faktor penyebab dan mendatangkan ketegangan stress yang dialami oleh tubuh. Rasa nyeri dan kelelahan merupakan stimulus yang menegangkan kapasitas-kapasitas (daya) psikologis atau fisiologis sehingga menjadi frustasi, di mana aktifitas yang terarah pada pencapaian tujuan telah terganggu, terhalang-halangi; peristiwa ini biasanya disertai oleh perasaan was-was kuatir dalam percapaian tujuan dan atau target tertentu. Oleh sebab itu, perlu dilakukan penelitian ini sehingga diharapkan dapat mengetahui pengaruh nyeri pada fasciitis plantaris yang disebabkan pekerjaan mempengaruhi kelelahan dan stress pada tenaga kerja.

\section{METODE PENELITIAN}

Penelitian ini menggunakan jenis Eksperiment, dengan menggunakan pendekatan rancangan one group pretest posttest. Rancangan ini juga tidak ada kelompok pembanding (control), tetapi paling tidak sudah dilakukan observasi pertama (pretest) yang memungkinkan menguji perubahan-perubahan yang terjadi setelah adanya eksperimen.

Populasi semua karyawan packing di PT TPS Food TBK yang menderita fascitis plantaris. Pengambilan sampel dilakukan secara consecutive sampling.

Penelitian ini diawali dari mengobservasi penderita fascitis plantaris. Nyeri Fasciitis plantaris adalah nyeri yang positif saat dilakukan plantar fascitis test. Secara khas, gejala-gejala permulaaan munculnya nyeri terjadi pada tumit bagian bawah selama beberapa langkah pertama pada waktu pagi atau setelah duduk pada waktu yang lama. Pada berkembangan gejala selanjutnya, nyeri dapat muncul pada setiap langkah dan terus - menerus (Merritt, 2010). Untuk mengukur penurunan nyeri pada fasciitis plantaris dengan alat ukur berupa Visual Analoc Scale dengan cara pengambilan datanya pada sehari sebelum terapi dilakukan dan sehari setelah terapi terakhir dilakukan (4 minggu). Pemeriksaan nyeri dilakukan pada kondisi nyeri gerak, nyeri diam, dan nyeri tekan. Pemeriksaan nyeri dilakukan sebelum dan sesudah perlakuan. Setelah didapat data baru bisa menentukan karyawan tersebut menderita fascitis plantaris atau tidak.

Setelah didapatkan sampel maka kemudian peneliti memberikan kuesioner tentang tingkat kelelahan dan tingkat stress, selanjutnya peneliti melakukan perlakuan atau eksperiment kepada semua sampel yang ada dan kemudian di test kembali tentang tingkat kelelahan dan tingkat stress melalui kuesioner yang sama. 


\section{HASIL PENELITIAN}

a. Pengaruh Medial Arch Support terhadap tingkat stress pada Penderita Plantar Fasciitis

Hasil uji normalitas dengan shapiro wilk diketahui bahwa nilai $p$ value derajat stress pretest sebesar $0,002<0,05$ sehingga data tidak normal dan $p$ value stress postest $0,303>0,05$ sehingga data terdistribusi normal, karena terdapat data yang tidak normal maka digunakan statistik non parametrik yaitu uji wilcoxon.

Tabel 1

Pengaruh Medial Arch Support terhadap Tingkat Stress pada Penderita Plantar Fasciitis

\begin{tabular}{clccc}
\hline Variabel & Perlakuan & Mean & T & p value \\
\hline Tingkat & Pretest & 47,43 & \multirow{2}{*}{$-4,603$} & \multirow{2}{*}{0,000} \\
stress & Postest & 35,00 & & \\
\hline
\end{tabular}

Hasil penelitian menunjukkan ratarata pretest stress penderita plantar fascitis $(47,43)$ sedangkan rata-rata postest $(35,00)$. Hasil uji statistik dengan wilcoxon menunjukkan $(p=0,000)$ sehingga terdapat pengaruh Medial Arch Support terhadap penurunan tingkat stress pada penderita plantar fasciitis.

b. Pengaruh Medial Arch Support terhadap Kelelahan pada Penderita Plantar Fasciitis

Hasil uji normalitas dengan shapiro wilk diketahui bahwa nilai $p$ value kelelahan pretest sebesar $0,002<0,05$ sehingga data tidak normal dan $p$ value kelelahan postest $0,000<0,05$ sehingga data terdistribusi tidak normal maka digunakan statistik non parametrik yaitu uji wilcoxon.
Tabel 2

Pengaruh Medial Arch Support terhadap Kelelahan Statis pada Penderita Plantar Fasciitis

\begin{tabular}{lllll} 
Variabel & Perlakuan & Mean & T & p value \\
& & & & \\
\hline Kelelahan & Pretest & 24,60 & - & \multirow{2}{*}{0,000} \\
& Postest & 20,20 & 4,312 & \\
\hline
\end{tabular}

Hasil penelitian menunjukkan ratarata pretest kelelahan penderita plantar fascitis $(24,60)$ sedangkan rata-rata postest (20,20). Hasil uji statistik dengan wilcoxon menunjukkan $p$ value $0,000<$ 0,05 sehingga terdapat pengaruh Medial Arch Support terhadap penurunan kelelahan pada penderita plantar fasciitis

\section{PEMBAHASAN}

a. Pengaruh penggunaan medial arch support terhadap penurunan tingkat stress pada pasien plantar fasciitis

Hasil penelitian menunjukkan bahwa terdapat pengaruh Medial Arch Support terhadap penurunan tingkat stress pada penderita plantar fasciitis dengan $p$ value $0,000<0,05$. Hal ini diperkuat dari rata-rata pretest stress penderita plantar fascitis $(47,43)$ sedangkan rata-rata postest $(35,00)$.

Hasil penelitian ini mendukung penelitian dari Rice (1999) yang menyatakan bahwa Physichal danger, yaitu sumber potensial yang dapat mengakibatkan stres kerja terutama saat pekerja menghadapi kemungkinan terluka yaitu pada kasus ini adalah plantar fasciitis sehingga diperlukan penggunaan medial arch support.

Penggunaan medial arch support pada kasus plantar fasciitis untuk mengurangi sensasi nyeri pada kaki, sehingga apabila para pekerja yang lebih banyak berdiri saat sedang bekerja menggunakan medial arc support dapat 
mengurangi nyeri pada kaki sehingga dapat menurunkan stress akibat adanya pengurangan rasa nyeri tersebut (Ewers, S, 2013).

b. Pengaruh penggunaan medial arch support terhadap kelelahan pada pasien plantar fasciitis

Hasil penelitian menunjukkan bahwa terdapat pengaruh Medial Arch Support terhadap kelelahan pada penderita plantar fasciitis dengan $p$ value $0,000<$ 0,05 . Hal ini diperkuat dari rata-rata pretest keseimbangan statis penderita plantar fascitis $(24,60)$ sedangkan ratarata postest $(20,20)$.

Hasil penelitian ini mendukung penelitian Green dan Suma'mur yang mengemukakan bahwa faktor yang mempengaruhi kelelahan ada dua yaitu faktor internal dan faktor eksternal. Yang termasuk faktor internal antara lain: faktor somatis atau faktor fisik, gizi, jenis kelamin, usia, pengetahuan dan sikap atau gaya hidup. Faktor fisik disini adalah adanya nyeri pada kaki (plantar fasciitis) dimana dalam hal ini memerlukan penggunaan Medial Arch Support yang merupakan jenis ortosis yang di pasang pada bagian medial arkus longitudinalis pedis. Fungsinya adalah sebagai shock breaker tumpuan berat badan pada kaki, untuk support bagian medial arkus longitudinalis pedis dan memberikan stabilitas pada kaki yang diharapkan dapat menurunkan rasa nyeri sehingga pekerja tersebut terbebas dari kelelahan.

\section{KESIMPULAN DAN SARAN}

1. Ada pengaruh Medial Arch Support terhadap penurunan tingkat stress pada penderita plantar fasciitis dengan $p$ value $0,000<0,05$.
2. Ada pengaruh Medial Arch Support terhadap penurunan kelelahan pada penderita plantar fasciitis dengan $p$ value $0,000<0,05$.

3. Bagi masyarakat khususnya penderita plantar faciitis dan orang di sekitarnya perlunya meningkatan pemahaman tentang upaya penanganan kondisi kaki plantar faciitis yang baik dan benar dalam pandangan medis sehingga dapat mencegah kecacatan lebih lanjut dengan konsultasi kepada ahli terapis.

4. Bagi Institusi pendidikan hendaknya berperan untuk memberikan edukasi dan meningkatkan pengetahuan masyarakat tentang peran dan manfaat ortotik prostetik perlu terus ditingkatkan melalui pemberian konsultasi ataupun mengadakan seminar kesehatan.

5. Bagi Praktisi Ortotis Prostetis, hendaknya terus mengadakan inovasi dengan melakukan penelitian tentang manfaat, kelebihan dan kekurangan dari bahan-bahan yang dipilih untuk mengembangkan pengetahuan ortotik prostetik dan pelayanan ortotik prostetik di masyarakat.

\section{DAFTAR RUJUKAN}

Ewers, S, 2013; Foot Orthosis; Cambodian School Prosthetic Orthotic, Kamboja, hal. 48.

Gunawan, Bambang Sumadiono. (2007). Stres dan sistem imun tubuh : suatu pendekatan psikoneuroimunologi. Pendidikan Profesi Fakultas Kedokteran Universitas Gadjah Mad bagian ilmu kesehatan anak sub bagian alergi imumologi. Yogyakarta. Cermin dunia kedokteran no. 154

Hafis, A. (2009). Manajemen stress. Skripsi. Universitas Negeri 
Sumatera

Utara.

http://www.scribd.com/doc/15962

943/MANAJEMEN-STRESS

Kuntarti, 2006, Mekanisme Kerja Otot saat Kontraksi, dalam Sistem

Gerak Manusia, Gramedia, Jakarta.

Levelers, 2012, Arches and Orthotic

Support, Germany

Mcpoil, Robroy, L, dkk, 2008; Heel Pain

Plantar Fasciitis: clinical practice guidelines linked to the international classification of functiong, disability and health from the orthopaedic section of the physical therapy association; orthop sport phys ther, hal. 38.

Oxford Dictionaries, Pengertian Foot , Diakses tanggal 15/08/14, dari http://www.oxforddictionaries.co $\mathrm{m} /$ foot.htm

Pudjiastuti,S.S.,dkk, $2010 \quad$, Pengaruh Penggunaan Medial Arch Support Terhadap Keseimbangan Dinamis pada Kondisi Flat Foot Anak Usia $6 \quad S / D \quad 8$ Tahun_, Poltekkes Kemenkes Surakarta, Surakarta. 